\title{
The Effect of Focused Meta-linguistic Written Corrective Feedback on Iranian Intermediate EFL Learners' Essay Writing Ability
}

\author{
Elahe Ebadi \\ English Language Department, Islamic Azad University, Garmsar Branch, Iran
}

\begin{abstract}
This study tried to investigate the possible effects of focused Meta-linguistic highlighted error feedback on grammatical accuracy of writing among Iranian intermediate EFL learners. After selecting 60 homogenous participants among 90 university students attending Ghaemshahr University and randomly assigning them to two intact groups of 30 students, the researcher exposed the participants of the experimental group to 12 sessions of the intended treatment. During the treatment sessions, the said individuals were exposed to focused meta-linguistic feedback upon the submission of the drafts of their essays; in comparison, the subjects in the control group, upon the submission of their essays, were corrected using traditional approaches. After the completion of the study and performing the due data analysis on the results, a significant progress was found among the subjects in the experimental group as compared to the control group.
\end{abstract}

Index Terms - focused meta-linguistic feedback, written corrective feedback, essay writing

\section{INTRODUCTION}

English language has been valued as one of the most broadly spoken languages. Knowledge of English language has become the basic requirement in most areas of all professions. When people want to learn English, they face various problems in their communication be it written or spoken.

Writing is considered as one of the most significant language skills in second or foreign language teaching and learning contexts. The ability to write proficiency in an academic context is the most important goal to a considerable number of L2 learners. Written texts produced by FL or SL learner contain a whole of array of grammatical and rhetorical errors. Usually, learners give a piece of writing in their instructor to be scored and when the instructor gives it back, it is usually put aside and forgotten as the learners begin a new writing. Should teachers provide some sort of feedback on the writing assignments of the language learners? And if so how, has been a matter of considerable debate in the field of second language acquisition (SLA). Any indication to learners by teachers that their use of the target language is incorrect is referred to as "written corrective feedback" (Lightbown \& Sapada, 1999).

Zamel (1983, as cited in Naidu, 2007) looks at the importance of feedback from a different perspective remarking that by studying what it is learners do in their writing, teachers can learn what learners still need to be taught". That is one important reason why the teachers' feedback is crucial in helping to improve learner writings. The teacher gives feedback and the teacher will help the learners see their mistakes and weaknesses and encourage them to overcome the problems in order to produce a more proficient text next time. This process is believed to be more effective in improving the learners' writing proficiency (Muncie, 2000; Myers, 1997).

The most popular way of feedback has been written comments on the student's final draft, pointing out problems and making suggestions for improvement of future papers. More recently, many teachers have started making comments on students' initial drafts, offering suggestions for the future development of the final drafts (Naidu, 2007).

\section{REVIEW OF LITERATURE}

Chastain (1988) stated writing is a main communication skill and a unique asset in the process of learning a second language. Both of these aspects are necessary in a common language class, and both can serve to improve the other. Writing may not be included in the goals of all language courses although it is usually included as one of the four language skills taught. In elementary courses, the focus is on writing as a fundamental process in learning the language. However, in advanced composition courses, the emphasis is primarily on writing as communication in addition to the fact that increased knowledge of language system in one of the by-products of writing to express one's ideas (p.244).

Depending upon the teacher, writing's goals may vary. Some teachers focus almost entirely on the language itself, some on communication and others on both the forms and the message. Writers should consider the reader, the effect they want to achieve, and the relationship they wish to establish with the reader. Furthermore, the creation of meaning, and the use of language and the correctness of grammar are to be taken into account. The long-term practical goal must be the ability to use the learned materials to communicate a message that a native speaker can understand. This applies to any course, with the accuracy requirements rising as the student advance in their study and practice with the language. 
Short-term goals are the same except that they apply to specific segments of the learning material (Chastain, 1988, p.245).

Considering the works done on the effect of the focused meta-linguistic corrective feedback in relation to writing ability we can see different and inconclusive results. According to Some researchers (e.g. Kepner, 1991; Sheppard, 1992; Truscott, 2007) state grammar correction does not have a positive effect on the improvement of L2 writing accuracy. Krashen (1982) and Truscott (2007) claim that corrective feedback (CF) is seen as not only ineffective but also potentially harmful. In contrast, other researchers (e.g. Bitchener and Knoch, 2008; Chandler, 2003; Ferris, 2002; Sheen, 2007) claim that CF is valuable in promoting greater grammatical accuracy.

Ellis, Sheen, and Murakami. (2008), for example, addressed the differential effects of focused and unfocused feedback on accuracy improvement of English as Foreign Language student writings. Both feedback methods helped long-term accuracy of EFL learners more than no feedback method. This indicated that CF is effective in itself, at least where English articles are concerned. However difference in the performance of focused and unfocused feedback groups was non-significant.

According to Ellis (2008), there are some theories which offer that focused CF is more successful than other types of feedback since learners are more likely to pay attention to those corrections which focus on specific error types.

Sheen (2007), for example, examined the differential effects of two approaches (direct and meta-linguistic) to focused feedback on the accurate use of English definite and indefinite articles in ESL student writings. This study showed that focused written CF helped improve ESL learners' accuracy, especially when meta-linguistic feedback was provided.

Sheen (2007) investigated the differential effects of the provision of direct focused written CF accompanied by oral meta-linguistic negotiation and mere direct written CF on the accuracy of EFL writing. The erroneous use of the forms in focus for the experimental group was negotiated in addition to CF provided, the erroneous use of the forms in focus was corrected through CF for the contrast group, and some comments on the quality of writings were provided for the control group. Both the experimental and the contrast groups showed improvement over time. The study showed that complementation of direct written $\mathrm{CF}$ and meta-linguistic discussion induced positive effects on writing accuracy, and that direct written $\mathrm{CF}$ with meta-linguistic discussion was superior to direct $\mathrm{CF}$ without such discussion.

\section{THE PRESENT STUDY}

\section{A. Statement of Problem}

Having worked as an English instructor for years, the researchers have noticed that in comparison to the other language skills, writing is most neglected by both students and teachers. It is also observed that a considerable number of teachers are not familiar with appropriate techniques to help their students improve their writing ability. In addition, majority of students, including those at higher levels of L2 learning, fail to use accurate grammar needed for acceptable writing. The nature of the procedures adopted by the teachers in grammar correction and giving feedback has constantly been an issue of great concern to the researcher.

According to Allwright (1995), Claudron (1977), and Long (1977) (as cited in Tatawy, 2002), several problems such as inconsistency, ambiguity and ineffectiveness of teachers' correction have been identified by the researchers. They put the lack of the effectiveness of corrective feedback down to the ambiguous and unsystematic approaches adopted by the majority of teachers.

According to Zamel (1985) (as cited in Tatawy, 2002), teachers provide students with contradictory comments on their written work and make arbitrary corrections. Moreover, it is not known to what extent the corrective feedback on linguistic errors determine accurate performance in writing. The most common method for providing corrective feedback on L2 writing in Iranian universities and language institutes is still traditional; language learners are assigned to write a paragraph or an essay on a particular topic. Their writings are then corrected by underlining and circling the errors and writing the correct form above or under the errors. And then they are given back to the learners. We call this kind of error correction direct error correction. What happens when the students receive their written work? Do they make sure that they understand the teacher's comments and objections? Not always. The researcher in this study seeks to explore the most efficient techniques for giving proper feedback to a written product made by L2 learners so as to introduce to the teachers of the most efficient ways of improving the accurate use of linguistic forms and structures in writing.

\section{B. Purpose and Research Question}

This study seeks to investigate whether focused Meta-linguistic corrective feedback can contribute to reaching the most appropriate ways of giving feedback in writing and to indicate that written corrective feedback can play a role in improving grammatical accuracy of Iranian learner's writing. The researchers correct the correction directed at selected grammatical points ( focused feedback), extra forms of focused feedback may include written meta-linguistic explanation (the provision of grammar rules and the example at the end of the student's script with a reference back to places in the text where the error has occurred) and spoken meta-linguistic explanation (e.g., a mini-lesson through which rules and examples are presented, practiced and discussed; conferences between teacher and small groups of students). 
The findings of this study can help instructors to provide their students with the most useful type of feedback to ensure their improvement in using accurate grammatical forms in writing. Moreover, these findings may lead to the increase in learner's self-awareness of their own improvement in writing. Therefore, this study aims to shed light on the answer to the following research question:

Does focused Meta-linguistic written corrective feedback have any significant effect on the accuracy in the production of specific grammatical forms in writing?

\section{Participants}

Total number of the participants was 47, selected from among two classes of essay writing who were then studying in Qaemshahr University. Of course, all the participants were majoring in English Translation. They were in two classes randomly assigned as experimental and control groups. 22 participants were chosen for the experimental group and 25 students for the control group. In order to increase the validity and reliability of findings, the study was conducted with the same teacher for both the control and experimental classes.

\section{Instruments}

In order to have reliable and valid results in this research, these instruments were implemented.

1- A Nelson test (general proficiency test) was used in order to determine the participants' level of proficiency and place the test takers in a single level of proficiency and selecting two nearly homogeneous groups. Experimental and control groups.

2- Since this research involved the writing skill, a writing test was necessarily used as a pre-test, and after the treatment sessions, the same test was used as a post-test. For this part of writing test from Interchange/Passages Placement and Evaluation Package test by Tay Lesely with Christa Hanson and Jean Zokowski/Faust (Cambridge University Press , Third Edition, 2005) was used.

\section{E. Procedure}

In order to collect data for this study several steps were taken. At first, the researchers needed to be sure that all the participants were at the intermediate level and the two groups had to be parallel regarding their level of proficiency, so a general proficiency test was administered. In order to choose students, the researcher used Nelson test for 65 students of Qaemshahr University. The research ranged students 'scores from highest to the lowest score and from among all the scores 47 students whose scores were in the middle of the whole range were selected. And the rest remained in classes without knowing that their final or post-test papers will not be included in the statistical procedures of the study. They were in two intact classes randomly assigned as experimental and control group. 22 participants were chosen for the experimental group and 25 students for the control group.

On the first session in both classes, the writing section B (appendix 2) of the interchange placement test was administered as the pretest to assess the participants writing ability in order to make sure that there was no statistically significant difference in the essay writing ability of the participants. And then to compare the results of the posttest to see how much progress each group had made. The essay written by the learners were scored by the three raters. And afterward the inter-rater reliability of the scores was calculated in order to determine the consistency of rating. After that, the researcher has twelve sessions between the pre-test and the post-test were divided into four parts. Each four sessions, one specific area of grammar was focused on and the students were given feedback only on that area. Three parts of linguistic errors were selected to be focused on within each four sessions. The researcher chose to be targeted in the research based on the frequency of their occurrence during the first writing task (the pre-test). The instructor chose a topic and participants had 30 minutes to write an essay about the topic, that specific error types were corrected by the teacher and who focused on particular structural errors and then explained the rule to participants. Next, the teacher asked them to produce another text with the same topic as before. He required them to submit their papers in order to receive feedback on their performance based on the specific error types which were targeted. This procedure took place within each four sessions with a different topic of writing and a specific error type to be corrected. On the last session in two classes, the writing section $\mathrm{C}$ (appendix 3) of the interchange placement test was administered as the posttest of the learners writing ability in order to see how much progress each group had made. The essay written by the learners were scored by the same three raters. And afterward the inter-rater reliability of the scores was calculated in order to determine the consistency of rating. Then the means of the scores of the control and experimental groups were compared through implementing the paired-sample T-test for determining the statistical significance of the difference between the means on the two sets of scores.

\section{RESULTS}

Initially to make sure participants were homogenized, the Nelson proficiency test was given to all of the participants of two classes which were selected for the purpose of this study. The results of this proficiency test are given in the table below. 
TABLE 1

DESCRIPTIVE STATISTIC FOR HOMOGENIZING TEST

Statistics

\begin{tabular}{|c|c|c|c|}
\hline & & first group & second group \\
\hline \multirow[t]{2}{*}{$\mathbf{N}$} & Valid & 32 & 33 \\
\hline & Missing & 1 & $\mathrm{O}$ \\
\hline \multicolumn{2}{|c|}{ Mean } & 33.2500 & 29.9394 \\
\hline \multicolumn{2}{|c|}{ Std. Error of Mean } & 1.51205 & 1.77948 \\
\hline \multicolumn{2}{|c|}{ Median } & 35.0000 & 31.0000 \\
\hline \multicolumn{2}{|c|}{ Mode } & 35.00 & 33.00 \\
\hline \multicolumn{2}{|c|}{ Std. Deviation } & 8.55344 & 10.22234 \\
\hline \multicolumn{2}{|c|}{ Variance } & 73.161 & 104.496 \\
\hline \multicolumn{2}{|c|}{ Skewness } & -.007 & -.039 \\
\hline \multicolumn{2}{|c|}{ Std. Error of Skewness } & .414 & .409 \\
\hline \multicolumn{2}{|c|}{ Kurtosis } & -.649 & -.743 \\
\hline \multicolumn{2}{|c|}{ Std. Error of Kurtosis } & .809 & .798 \\
\hline \multicolumn{2}{|c|}{ Range } & 33.00 & 39.00 \\
\hline \multicolumn{2}{|c|}{ Minimum } & 17.00 & 11.00 \\
\hline \multicolumn{2}{|c|}{ Maximum } & 50.00 & 50.00 \\
\hline \multicolumn{2}{|c|}{ Sum } & 1064.00 & 988.00 \\
\hline
\end{tabular}

As indicated in table 1, the mean score of first group was 33.25 and the mean score of second group was 29.93 . Descriptive statistics for the two groups in pre-test are displayed in table 2.

TABLE 2

DESCRIPTIVE STATISTIC PRE-TEST OF WRITING BY GROUPS

\begin{tabular}{|l|l|l|l|l|l|}
\hline \multicolumn{2}{|c|}{ Groups } & $\mathrm{N}$ & Mean & Std.Deviation & Std.Error Mean \\
\hline Pretest & Exp & 22 & 14.18 & 3.59 & .44 \\
\cline { 2 - 6 } & Con & 25 & 14.88 & 3.53 & .40 \\
\hline
\end{tabular}

The mean score achieved by participants of the experimental group on the pre-test was 14.18, while their counterparts in the control group achieved a mean score of 14.88 .

And in order to see whether the two groups were also homogenous regarding their essay writing ability or not. The means between the pre-tests obtained from the two groups were compared using the paired-samples t-test.

TABLE 3

Paired Samples Test

\begin{tabular}{|c|c|c|c|c|c|c|c|c|c|}
\hline & & \multicolumn{5}{|c|}{ Paired Differences } & \multirow[b]{3}{*}{$t$} & \multirow[b]{3}{*}{ df } & \multirow[b]{3}{*}{ Sig. (2-tailed) } \\
\hline & & \multirow[b]{2}{*}{ Mean } & \multirow[b]{2}{*}{ Std. Deviation } & \multirow{2}{*}{$\begin{array}{l}\text { Std. Error } \\
\text { Mean }\end{array}$} & \multicolumn{2}{|c|}{$\begin{array}{l}95 \% \text { Confidence } \\
\text { Interval of the } \\
\text { Difference }\end{array}$} & & & \\
\hline & & & & & Lower & Upper & & & \\
\hline $\begin{array}{l}\text { Pair } \\
1\end{array}$ & $\begin{array}{l}\text { control group in pre } \\
\text { test - exprimental } \\
\text { group in pre test }\end{array}$ & .46970 & 4.69769 & .57825 & -.68514 & 1.62453 & .812 & 65 & .420 \\
\hline
\end{tabular}

The results of the paired-samples t-test shown in table 3 demonstrate that homogeneity of the scores between the two groups. The column labeled sig. (2-tailed) is our probability value. If this value is less than .05 (e.g. .04, .01, .001), then it can be concluded that there is a significant difference between the two sets of scores (pallant, 2002, p.212). In this table, the probability value is .42 . This means that the probability value was more than $.05(\mathrm{p}=.42>.05)$ indicating that the control and experimental groups 'scores were not significantly different from each other. Therefore, it was made certain that the groups were actually homogeneous.

The descriptive statistics for the two groups in post-test are displayed in table 4 .

TABLE 4

DESCRIPTIVE STATISTICS POST-TEST OF WRITING BY GROUPS

\begin{tabular}{|l|l|l|l|l|l|}
\hline \multicolumn{2}{|l|}{ Groups } & N & Mean & Std.Deviation & Std.Error Mean \\
\hline Posttest & Exp & 22 & 15.54 & 3.24 & .39 \\
\cline { 2 - 6 } & Con & 25 & 14.40 & 3.54 & .40 \\
\hline
\end{tabular}

This table shows that the mean score achieved by participants of the experimental group on the post-test was 15.54 , while in the control group achieved a mean score of 14.40 .

Then the means between the post-test obtained from the two groups were compared using the paired-samples t-test in order to see which of the two groups had made more progress in writing skill. 
TABLE 5

Paired Samples Test

\begin{tabular}{|c|c|c|c|c|c|c|c|c|c|}
\hline & & \multicolumn{5}{|c|}{ Paired Differences } & \multirow[b]{3}{*}{$\mathrm{t}$} & \multirow[b]{3}{*}{$\mathrm{df}$} & \multirow[b]{3}{*}{ Sig. (2-tailed) } \\
\hline & & \multirow[b]{2}{*}{ Mean } & \multirow[b]{2}{*}{ Std. Deviation } & \multirow{2}{*}{$\begin{array}{l}\text { Std. Error } \\
\text { Mean }\end{array}$} & \multicolumn{2}{|c|}{$\begin{array}{l}95 \% \text { Confidence } \\
\text { Interval of the } \\
\text { Difference }\end{array}$} & & & \\
\hline & & & & & Lower & Upper & & & \\
\hline $\begin{array}{l}\text { Pair } \\
1\end{array}$ & $\begin{array}{l}\text { CONTROL GROUP - } \\
\text { EXPRIMENTAL GROUP }\end{array}$ & -1.50000 & 4.42458 & .54463 & -2.58770 & -.41230 & -2.754 & 65 & .008 \\
\hline
\end{tabular}

The result of comparing the mean performance of the two groups in posttest has been reported. In this table, the probability value is .008 . This means that the probability value was less than $.05(p=.008<.05)$ indicating that the mean performance of the two sets of scores in post test are significantly different and the focused meta-linguistic feedback group has outperformed the traditional-based writing group.

\section{DisCUSSION \& CONCLUSION}

The type of the techniques used by the teachers for grammar correction and giving feedback has been a matter of controversy. It is observed that teachers utilize various techniques so as to help their students improve their writing ability. One of the most popular methods is to give relevant feedback based on errors made by a learner.

The aim of this study was to investigate the effect of focused meta-linguistic Written Corrective Feedback on Iranian Intermediate EFL Learners' Essay Writing Ability. The result of t-test revealed a significant difference between the performance of the students in the experimental and control groups. Based on the result, it was inferred that the experimental group performed better than the control group due to employing focused meta-linguistic CF as treatment. So it can be concluded that focused meta-linguistic CF can be used for not only revising students writing but also for instructional purposes. Employing focused meta-linguistic CF improves Iranian EFL learners writing ability. In other words, employing focused meta-linguistic feedback led to a significantly fewer errors in writing and helped learners to become aware of their own errors and monitor themselves. The student become more independent learners and develops autonomy.

The results of this study showed that the participants considered focused meta- linguistic CF to be a very effective method because they could learn English grammar rules from their own errors by applying their grammar knowledge in writing, they could become aware of their common mistakes through the teacher's constant error feedback and reduce those errors, and correcting their own errors in their essays helped them improve their writing skills and accuracy. However, the results of this study could not be generalized to all L2 writing contexts because as Ferris (2006) stated, students might make use of the feedback they are provided with in different ways. Nevertheless, based on the findings of this study, we can conclude that focused meta-linguistic CF would most probably be more efficacious in comparison with the traditional based corrective feedback.

The results of the current study can be used in all educational centers. They have direct or indirect implications for and applications to teaching, learning, test development, syllabus design and material development. This study, according to the achieved results, may have some hints for English teachers who might, for sure, pay attention to teaching writing or any other four major skills: listening, speaking, reading, and writing because focused meta-linguistic corrective feedback cannot be limited to any skills or subjects in isolation.

The main pedagogical implication of corrective feedback in general has addressed the teachers' role not only in motivating the students to make use of accurate language forms and structures, but also in spotting learners' errors and providing them with the most appropriate kind of feedback in order to confirm their improvement in writing more accurately.

Therefore, language teachers, institutes, universities, and the Ministry of education take an important part in promoting student's understanding of focused meta-linguistic corrective feedback and its application in every field of study and subject, language learning and teaching, etc. university and institute teachers and professors should help each other to enhance and develop focused meta-linguistic corrective feedback for all areas of study.

\section{REFERENCES}

[1] Allwright, R. (1995). A First Langauge; the Early Stages. Harvard University Press, Cambridge, MA.

[2] Bitchener, J., Knoch, U. (2008). The value of written corrective feedback for Migrant and international students. Language Teaching Research 12 (3), 255-270.

[3] Chandler, J. (2003). The efficacy of various kinds of error feedback forImprovement in the accuracy and fluency of L2 student writing. Journal of Second Language Writing 12,267-296.

[4] Chastain, K. (1988). Developing Second Language Skills Theory and Practice. Third edition. Harcourt Brace Jovanovich.

[5] Claudron, V. (1977). Designing Feedback for Computer-Based Training. Performance and Instruction, 34, 18-23.

[6] Ellis, R. (2008). The Study of Second Language Acquisition. Oxford: Oxford University Press.

[7] Ellis, R., Sheen, Y., Murakami, M. (2008). The effects of focused and unfocused written corrective feedback in English as a foreign language Context. System, 36, 353-371. 
[8] Ferris, D. R. (2002). Treatment of error in second language student writing. Ann Arbor: University of Michigan Press.

[9] Ferris, D. R. (2006). Does error feedback help student writers? New evidence on The short and long-term effects of written error correction. In K. Hyland \&F. Hyland (Eds.), feedback in second language writing: contexts and issues. (pp. 81-104). Cambridge: Cambridge University Press.

[10] Kepner, C.G. (1991). An experiment in the relationship of types of written Feedback to the development of second language writing skills. Modern Language Journal 75, 305-313.

[11] Krashen, S. (1982). Principles and practice in second language acquisition. Oxford: Pergamon Press.

[12] Lightbown, P.M. \& Spada, N. (1999). How languages are learned (2 ${ }^{\text {nd }}$ ed.).Oxford: Oxford University Press.

[13] Long, M. (1977). Focus on form: A design feature in language teaching methodology. In K. DeBot, R. Ginsberg, \& C. Kramsch (Eds.), Foreign Language research in cross-cultural perspective (pp.39-52). Amsterdam: Benjamins.

[14] Muncie, J. (2000). Using written teacher feedback in EFL composition classes. ELT Journal, 54(1), 47-53.

[15] Myers, J. (1997). "Second language writing and research: The writing process and error analysis in student texts". Teaching English as a Second or Foreign Language, vol.6 (2), 361-386.

[16] Naidu, B. (2007). Theories of second language learning. London: Edward Arnold.

[17] Pallant, K. (2002). How languages are learned ( $2^{\text {nd }}$ ed.). Oxford: Oxford University Press.

[18] Sheen, Y. (2007). The effect of focused written corrective feedback and language Aptitude on ESL learners' acquisition of articles. TESOL Quarterly, 41, 255-283.

[19] Sheppard, K, (1992). Two feedback types: do they make a difference? RELC Journal 23, 103-110.

[20] Tatawy, M. (2002). Corrective feedback in second language acquisition. Working Papers in TESOL \& Applied Linguistic 2:2 http:// www.tc.columbia.edu/ academic/tesol/Webjournal/ El-Tatawy.pdf.

[21] Truscott, J, 1996. The case against grammar correction in L2 writing classes. Language Learning 46, 327-369.

[22] Truscott, J, (1999). The case for "the case for grammar correction in L2 writing Classes": a response to Ferris. Journal of Second Language Writing 8, 111-122.

[23] Truscott, J, (2007). The effect of error correction on learners' ability to write Accurately. Journal of Second Language Writing. $16,255-272$

[24] Zamel, V. (1983). The composition processes of advanced ESL students: Six case Studies. TESOL Quarterly, 17(2), 165-178.

[25] Zamel, V. (1985). Responding to student writing. TESOL Quarterly, 21, 697-715.

Elahe Ebadi is an MA graduate student in TEFL at University of Garmsar, Iran. She was born in Mazandaran, Iran. She received her BA in English translation in 2007 from Qaemshahr University, Mazandaran, Iran. She is currently teaching English in private language institutes in Mazandaran. Her area of interest includes language teaching and learning techniques and strategies. 